\title{
Impact of Brand Awareness and Social Media Content Marketing on Consumer Purchase Decision
}

\author{
Sinoka Ansari ${ }^{* 1}$, Ghishwa Ansari ${ }^{2}$, Muhammad Umar Ghori ${ }^{3}$, Abdul Ghafoor Kazi ${ }^{4}$ \\ ${ }^{1,2,3,4}$ Department of Management Sciences, Shaheed Zulfiqar Ali Bhutto Institure of Science and Technology (SZABIST), Hyderabad, Pakistan.
}

*Corresponding author: sinokaansari@hotmail.com

\begin{abstract}
The purpose of this study was to examine the impact of brand awareness and social media content marketing on the consumer purchase decision. The data for this research was collected through an online questionnaire. The total number of respondents for this study were 150 (60\% females; $40 \%$ males). The objective of this research was to investigate the relationship between brand awareness and social media content marketing with the consumer purchase decision. However, results indicate that brand awareness has a weak positive significant relationship with consumer purchase decision whereas, social media content marketing has a moderate positive significant relationship with the consumer purchase decision.
\end{abstract}

\section{ARTICLE INFORMATION}

Received: 13 April 2019 Revised: $\quad 02$ July 2019 Accepted: 28 July 2019 DOI: $10.31580 /$ jpvai.v2i2.896

Keywords: Brand Awareness, Social Media Content, Purchase Decision, Media Marketing, Quantitative Study Pakistan

\section{INTRODUCTION}

In today's era, social media has become an important platform to connect individuals around the world. They use social media to interact and share something with their friends and peers through online conversation. Social media includes two participants i.e. users and web publishers along with a platform where these individuals connect and exchange information (Touchette \&Schanski, 2015). Whereas Evans (2008) defined social media as a medium of communication where people with the same minds connect and interact with each other to share their life experiences. However, social media is all about online communication, sharing of information and ideas through an electronic mode. It is the integration of technology, socialization and sharing of thoughts through words or visual aids.

The rise and growth in technological advancement have evolved many opportunities for businesses. There are many online platforms which assisted businesses in escalating their sales and profit margins. This change in the business globe has controlled the functions of social media to be a marketing tool in creating brand awareness and growth. This business evolution began with Web 1.0 which now has emerged as Web 3.0. It has helped businesses in developing marketing strategies and measuring brand awareness through online social platforms. Web 3.0 has set new standards for online socialization with different ways of establishing websites more creatively. Furthermore, it will make things easier for businesses and consumers in connecting through better search system where they can easily find their desired products.

Brands create their pages on social networking sites where they share the product insights to inform consumers, they share their content through videos or images in order to grab the target market's attention towards the brand products. A healthy content will help the brand in delivering better and will assist brands in engaging audiences in the brand activities so that they remain associated with it. However, according to some business practitioners, content marketing is a marketing strategy by businesses in order to create and disperse valuable, consistent and pertinent information to grab maximum market shares and escalate profits (Content Marketing Institute, 2015). Content marketing is a technique through which companies share valuable insights consistently to acquire market shares along with the purpose of gaining profitable customer movement (Steimle, 2014). Moreover, if the content is of interest to the consumers then they will actively participate and get involved in the brand activities. As the content promotes information about the brand and its offerings this content will help consumers in getting associated with the brand and building a prosperous relationship among brands and consumers. This connection attracts consumers and encourages them to purchase the product.

Initially, brands did not have much exposure to reach their target market or deliver the information effectively. They use to market their products through traditional marketing techniques i.e. newspapers, magazines, radios and then later on through television. However, it only helped in informing the consumer about the availability of products without knowing the actual needs and demands of the consumers. Brands used to only sell manufactured products. Whereas in this modern technology-driven era, brands produce the products according to their consumers need, consumers demand the products and then brands work on bringing consumers to demand into practicality.

The content marketing technique has played a major role in building a strong connection and engaging with the consumers, it helps the company in enhancing its market shares by posting content on their social networking platforms (Potgieter \& Naidoo 2017; Rosenthal \& Brito 2017).

There have been a number of studies on social media marketing, brand awareness and consumer purchase decision. However, after going through these studies there is still a need to study the relationship of social media content marketing and brand awareness 
with the consumer purchase decision. The purpose of this study was to examine the importance of social media content marketing and brand awareness in creating consumers' purchase decision. The objectives are

- To examine the relationship of brand awareness with the consumer purchase decision.

- To investigate the relationship of social media content marketing with the consumer purchase decision.

The research questions are:

- Does brand awareness affect consumer purchase decision?

- Does social media content marketing play a role in creating consumer purchase decision?

\section{LITERATURE REVIEW}

Brand Awareness: Brand awareness refers to consumers consciousness about the brand and products offered by it. It is the most significant thing for any company to provide the best possible information about their brand and its offerings to the people in order to attract their potential consumers. Brand awareness through social media plays a major role in increasing market shares for the brands as it is an influential tool for consumer repetitive buying behavior. Brands must use different tactics to keep their target audiences engaged in brand activities through post updates (images, videos or articles). The content of the post, however, should be inspiring and impressive to read. Nowadays companies are experimenting through different tools to interact with their current and potential customers, for instance, "Hashtags" is one of them. Through hashtags, companies can display their ideas and concepts. Along with that, popular hashtag words can also be used by the brands which define their market in order to increase their page visits and brand awareness (Daeun Kim, 2017). Karamian, Nadoushan M.A., Nadoushan A.A. (2015) used social media marketing as a factor in determining brand awareness in their study. Celebrity endorsement is one of the factors that can help in creating awareness for a brand in the market. There are certain dimensions to measure the credibility of a celebrity that includes trustworthiness, familiarity and expertise to positively influence brand awareness. Celebrities being a public figure can work as a bridge in connecting individuals with a brand (Kim, Choeb, Petrick J., 2018).

Consumers experience brands in a variety of ways and one of them is through social media marketing activities, where active consumers get engaged with the brand and enhance the brand page views which leads to greater brand awareness (Hutter et.al., 2018). Building brand awareness is one of the key tasks of marketers. Brands create their online social pages or profiles in order to attract their target market, engage them and convert into sales. The brands can enhance their brand awareness by stimulating virtual interactivity, offering rewards and providing better information system (Barreda et.al., 2015). Brand awareness is created by establishing customer relationship and earning their trust in the brand's products. Each brand creates their own content marketing program through which they measure their brand awareness on social media, such measures include social media reach, brand mentions, blog shares and search volume (Hines, 2017).

This study determines brand awareness through social media by understanding the importance of brands in their lives, to examine the reason behind following brands on social networking sites and the ways through which they receive information about brands.

\section{Social Media}

Social media is a platform that allows the user to create and exchange content among each other. It is a group of applications that are built on the technical basis of web 2.0 (Whiting \& Williams, 2013). Consumers are using social media with both hands (Patino, et al., 2012). Initially, there were not many platforms for brands to interact with customers or build long-term relationships (Vanauken, 2014). One can say that social media is an online medium of interaction. It can be done by any individual who has access to the internet where they can create, share and publish their ideas and experiences. The content of their ideas and experiences can be in the form of images, text, videos and audios (Halpin, 2013). Social media is an independent feature that allows consumers to connect and disconnect whenever they feel like, hence satisfying their instinct (Patino, et al., 2012). Social media is considered to be the biggest change since the revolution of industry (Phillips, 2013).

\section{Social MEDIA MARKETING}

As time goes by people are spending more time on the internet especially on social media sites like Facebook, LinkedIn and Instagram (Davidsson\&Findahl 2016). Researches show that brands are now investing in digital marketing areas more rather into traditional marketing (Baines \& Fill 2014). According to Baines \& Fill (2014), social media marketing is a digital platform for conducting marketing activities. enterprises in this modern technical era have no more control on how they are perceived in the market, consumers nowadays are actively engaged in brand offerings, they have the access to comment, share and create information easily. Social media has made things transparent as it reveals the good, bad or ugly regarding a brand which can get viral easily through shares.

\section{Content Marketing}

According to the Content Marketing Institute, "Content marketing is a marketing technique of creating and distributing valuable, relevant and consistent content to attract and acquire a clearly defined audience - with the objective of driving profitable customer action". It seeks to answer the queries, assisting the consumers in resolving their problems at hand and the decision-making process, rather than focusing on the brand or company (Templeman, 2015). The key purpose of content marketing as identified by (Pulizzi, 2012):

- Customer perspective reinforcement;

- Sales and lead generation;

- Consumer Engagement;

- Brand awareness;

- Customer upsells

- Enthusiastic Followers, fans and subscribers

\section{CONTENT MARKETING TACTICS}

Content can be in the form of blogs, videos, case studies, infographics, e-books, images, professional reviews, etc. The broadly used content marketing techniques by B2C companies are social media networks, website articles, blogs and vlogs. Whereas, videos are considered to be the most effective marketing technique for sharing company insights with consumers. (North America Report, 2014)

\section{USER-GENERATED CONTENT}

The concept of User-generated content tends to be more productive in connecting with the consumers, where they can contact, engage and express themselves and contribute in creating content (Huotari, et al., 2015). The user-generated content helps in building virtual communities for the brand which eventually enhances the brand image as well (Holliman \& Rowley, 2014). It is observed that young consumers are more actively participating in sharing their views regarding a product or service they experience by different brands (Hsu, et al., 2013). A healthy content by the brand can help the brand in retaining its customers who can become the advocates for the brand in future and help the company in attracting the potential target market by posting reviews on the social media platforms and spreading a positive word of mouth for the company (Hur, et al., 2011).

The youth today is more attracted towards social media marketing on social networking sites where they are more active rather than the traditional marketing sources like radio, newspapers, TVCs etc. 
Consumers require instant access to the information for their convenience. They are interested in using several types of social media accounts to search for the required information and eventually make purchasing decisions (Lempert, 2006; Vollmer \&Precourt, 2008). However, this study determines social media marketing by checking the number of profiles using social networking sites, the medium that the users are more engaged in along with their input about the marketing campaign of brands on social media.

\section{Purchase Decision}

The purchase decision is the decision-making process by consumers regarding a transaction of goods or services being offered in the market. The market provides a wide pool of brands offering almost the same products with different values in order to attract consumers. Since this is a technologically driven era, therefore, social media is the platform for brands to display their offerings along with the product information to save consumers time and attract them towards the brand. Dehghani and Tumer (2015) in their study on Facebook effectiveness considered brand image and brand equity as the two factors for determining the purchase intention of the buyers. With the change of time and trends, consumer purchase behavior has also changed, they usually inquire about the brand quality before making a purchase decision, therefore, consumers tend to watch vloggers reviews before making a purchase decision in order to get themselves the most suitable product for their consumption (Daeun Kim, 2017). The virtual communities of brands on social media are generating consumer participation and trust towards brands. This trust is developed through information and experience sharing by the users of the brand that help the prospective buyers in overcoming their concerns regarding the product and thus leads to purchase desire. According to the study, the independent variables for purchase decision were eWOM, brand loyalty, and social media marketing (Hajli, 2014).

A consumer's "buying decisions are influenced by perceptions, motivations, learning, attitudes and beliefs" (Lamb et al., p.91). The brand image and quality of the product are considered to be the main factors in contributing to consumer purchase intention along with some motivation by the reviews and feedback of those who have already experienced it (Gogoi, 2013).

\section{E-WOM and Brand Advocates}

It has been observed through different studies that the reviews given by friends or users of the product on social media put twice times more trust in the consumers' mind that the marketing campaign by the brand itself (Ludwig, et al., 2013). The eWOM is a statement made by consumers on social networking platforms, this statement could be either positive or negative. A study conducted on online retailing claimed that about $73 \%$ of their respondents agreed with the fact that brands' consumer reviews and comments regarding a product help them in overcoming their concerns and encouraged them in making online purchases (Mintel, 2015). In order to escalate the word of mouth for brands, it is important to consistently share the brand insights with consumers on virtual communities and keep them updated through the content marketing (CMO MindJet Corporations, Lisa Arthur). However, blogging is observed to be the most effective form of eWOM in the marketing point of view (Hsu et.al, 2013). A study conducted on online retailing claimed that about $73 \%$ of their respondents agreed with the fact that brands' consumer reviews and comments regarding a product help them in overcoming their concerns and encouraged them in making online purchases (Mintel, 2015)

Consumers nowadays rely on their friend's suggestion about any product on social networks. As per (Mintel, 2015) around 21\% of consumers in Ireland have had good experience with the products that have reviews on social media given by their peers.

However, this study determines consumer purchase decision through social media by their expression of choice regarding the online medium through which they check brand updates and how does it help them in making up their minds for the product purchase.

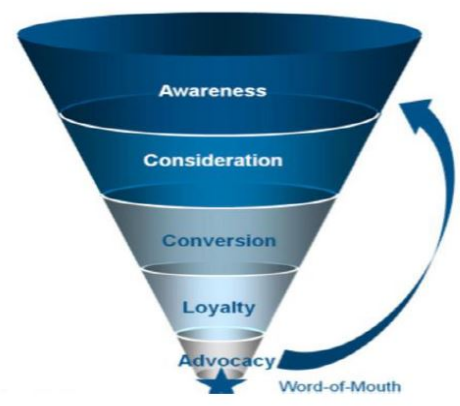

Fig 1.

Previous researches have conducted studies on different aspects of the consumer purchase decision. This study focuses on examining the relationship between consumer purchase decision with brand awareness and social media content marketing. This research considers consumer purchase decision as a dependent variable and brand awareness along with social media content marketing as an independent variable. This study will examine the below-given factors and their relationship with the variables.

Factors for Brand Awareness:

- Hashtags

- Blog shares

Factors for Social Media Content Marketing:

- Vlogger reviews

- Electronic Word of mouth

Social media has grown into a giant tool through which brands connect and interact with their consumers. Brands need to understand the importance of social media as it helps in promoting the brand and creates brand awareness among individuals (Irfan et al,. 2019; York, 2015). The content marketing assists brands in delivering brand information through social media sites that create awareness for brands and changes consumers' approach regarding its products (Odden, 2013). Therefore this study tests the hypothesis;

$\mathrm{H1}$ : Brand awareness has a significant relationship withthe consumer purchase decision

Content is said to be a building block for brands in connecting with customers, it is the quality of a content that attracts customers towards any brand. Companies should work on the quality of the content rather than quantity since it is the content that encourages customers to make a purchase decision (Puro, 2013). The content marketing works as a relationship building technique through which customers can associate themselves with brands and if the content is strong enough then it leads consumers to purchase decision as well (Odden, 2013). A creative marketing strategy includes a proper content in form of text along with designing structures and the appropriate execution that encourages the probability of the desired outcome on the target market (Irfan et al., 2017; Ashley and Tuten, 2015). Therefore this study will test the hypothesis,

$\mathrm{H} 2$ : Social media content marketing has a significant relationship with the consumer purchase decision.

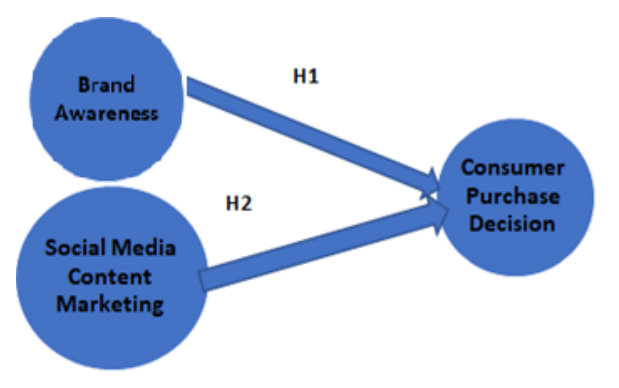

Fig 2. Research Framework 


\section{METHODOLOGY}

The purpose of this study is to examine the impact of social media content marketing on brand awareness and consumer purchase intention. The study used brand awareness and consumer purchase intention as dependent variables and social media content marketing as an independent variable. This study will examine consumers' purchase decision by using brand awareness and social media content marketing as independent variables. Therefore, the research type for this study is quantitative research, which means it will focus on the numerical results and analysis of data rather than personal opinions. For this study, a quantitative research method is used to gain consumer insights. This method is quick, inexpensive and it can anticipate the hypothesis. The sample size for the online survey questionnaire was 150 including male and female from the age group of 15 to 28 years. In order to collect relevant data, the study has conducted a questionnaire survey comprising 15 questions belonging to demographics, social media content marketing, brand awareness and consumer purchase decision respectively.

The data for this study was analysed through the Statistical Package for Social Sciences (SPSS). The tests run through SPSS between variables were multiple regression analysis and coefficient correlation analysis in order to reach the conclusion.

The research model used in this study is:

$\mathrm{Y}=\alpha+\beta \mathrm{X}+\mu$

Where;

"Y" is a variable which is dependent.

" $\alpha$ " is a constant.

" $\beta$ " is a coefficient of independent variables.

" $\mathrm{x}$ " is an independent variable.

" $\mu$ " is an Error term.

Based on the selected variables, the multiple regression equation of the study would be:

Consumer Purchase Decision $=\alpha+\beta($ BRANDAWARENESS $)+$ $\beta(\mathrm{SMCM})+\mu$

\section{DATA ANALYSIS}

The descriptive statistics include the minimum, the maximum, mean and standard deviation of the dependent and independent variables. In order to determine the relationship between variables and their interpretation, the Correlation Coefficient test is performed Along with that, the other test performed is Multiple Regression Analysis which has measured the relationship among the variables and the impact on the dependent variable due to the changes in the independent variable.

Figure 3 mentions that $56 \%$ of the respondents belong to the age group of $15-18$ years, $36 \%$ were aged between $19-21$ years, $6.67 \%$ of the respondents were from the age group of $22-25$ and $1.33 \%$ of them were aged between 25-28 years. Hence, most of the target audience fell in 15 to 18 years' age group.

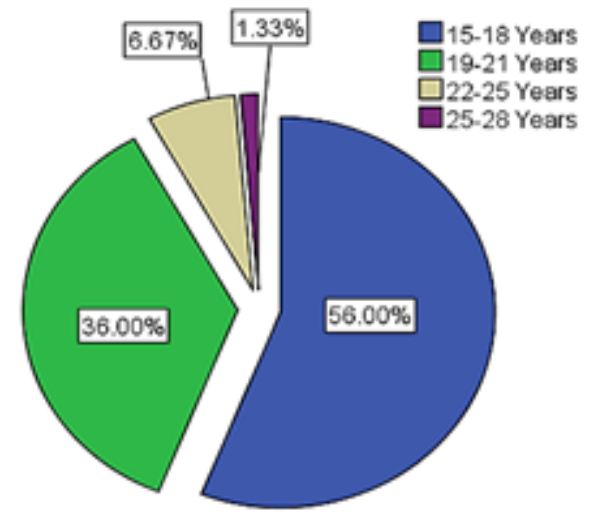

Fig 3. Age
Figure 4 shows that $60 \%$ of the respondents were female and $40 \%$ of them were male. Hence, the majority of the responses were gathered through females.

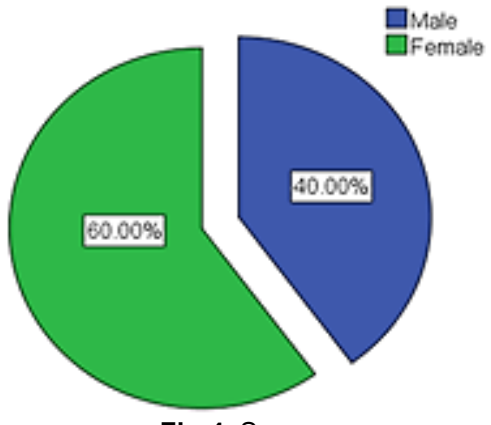

Fig 4. Sex

Figure 5 presents that the occupational background of the respondents where $58.6 \%$ were students, $32 \%$ of the respondents were employed whereas, $9.33 \%$ of them were unemployed. Hence, the majority of the responses were collected from students.

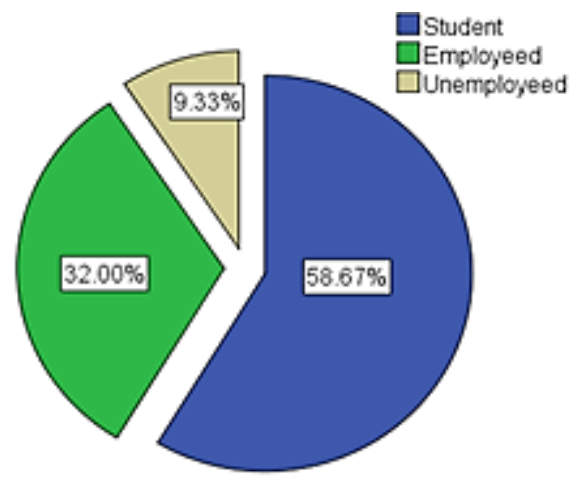

Fig 5. Occupation

The below-given table defines the descriptive statistics including minimum, maximum and standard deviation of the variables.

\begin{tabular}{lcccccc}
\multicolumn{7}{c}{ Table 1. Descriptive Statistics } \\
\hline Variable & N & Min & Max & Mean & $\begin{array}{l}\text { Std. } \\
\text { Deviation }\end{array}$ \\
\hline Brand Awareness & 150 & 2 & 5 & 3.46 & .796 \\
$\begin{array}{l}\text { Social Media Content } \\
\text { Marketing }\end{array}$ & 150 & 2 & 5 & 4.09 & .745 \\
$\begin{array}{l}\text { Purchase Decision } \\
\text { Valid N (listwise) }\end{array}$ & 150 & 2 & 5 & 3.76 & .659 \\
\hline
\end{tabular}

The $\mathrm{N}$ in the Table 1 shows the total number of samples, which is 150. Whereas the mean represents average value and the standard deviation shows the deviation of values around the mean.

Consumer Purchase decision has minimum value 2 and the maximum value 5. The mean Consumer Purchase decision is 3.76 and the standard deviation is 0.659 . Brand Awareness has 2 and 5 minimum and maximum values with a mean of 3.46 and a standard deviation of 0.796 . Social media content marketing has minimum value 2 and maximum value 5 with a mean value of 4.09 and 0.745 of standard deviation.

\section{Correlation Coefficient}

The correlation coefficient is a measure of relationship which is denoted by ' $r$ '. It tells the relationship between two or more variables whether there is positive, negative or no relationship at all. It also shows that how much strong or weak the relationship is. The value of ' $r$ ' lies between -1 and +1 . The value of $r$ can be interpreted as:

- Exactly -1 . Means there is a perfect negative relationship between variables. 
- $\quad$ 0.70. It means there is a strong negative relationship between variables.

- 0.50. It shows that there is a moderate negative relationship among variables.

- $\quad 0.30$. It means there is a weak negative relationship between variables.

- 0 . Means there is neither positive nor negative relationship among variables.

- +0.30 . It shows a weak positive relationship between variables.

- +0.50 . It means that there is a moderate positive relationship among variables.

- $\quad+0.70$. It shows a strong positive relationship between variables.

- Exactly +1 . Variables have a perfect positive relationship with each other.

\begin{tabular}{|c|c|c|c|}
\hline Variable & $\begin{array}{l}\text { Brand } \\
\text { Awareness }\end{array}$ & $\begin{array}{l}\text { Social Media } \\
\text { Content } \\
\text { Marketing }\end{array}$ & $\begin{array}{l}\text { Purchase } \\
\text { Decision }\end{array}$ \\
\hline Brand Awareness & 1 & $.396^{* \prime}$ & $.406^{\mathrm{*x}}$ \\
\hline $\begin{array}{l}\text { Social Media Content } \\
\text { Marketing }\end{array}$ & $.396^{* *}$ & 1 & $.573^{* *}$ \\
\hline Purchase Decision & $.406^{* *}$ & $.573^{* *}$ & 1 \\
\hline
\end{tabular}

Table 2 interprets that the correlation between brand awareness and consumer purchase decision is 0.406 which suggests that brand awareness has a weak but positive relationship with the consumer purchase decision. The correlation between social media content marketing and consumer purchase decision is 0.573 , which means that they have a moderate and positive relationship. When brand awareness increases the value of consumer purchase decision rises or vice versa. Social media content marketing has a positive significant relationship with brand awareness which indicates that when the value of one independent variable rises/declines then the value of another independent variable will rise/decline as well.

When there are two or more independent variables then it is said to be multiple regression. It helps in estimating the value of the dependent variable on the basis of the independent variable. Through this model, one can easily determine how much each variable is contributing to the total variance in the study. Furthermore, the acceptance or the rejection of the hypothesis is purely based on the results of multiple regression.

Table 3. Variables Entered/ Removed ${ }^{\mathrm{a}}$

\begin{tabular}{llll}
\hline Model & Variables Entered & $\begin{array}{l}\text { Variables } \\
\text { Removed }\end{array}$ & Method \\
\hline 1 & $\begin{array}{l}\text { Social Media Content Marketing, } \\
\text { Brand Awareness }\end{array}$ & Enter \\
& a. Dependent Variable: Purchase Decision & \\
b. All requested variables entered. & & \\
\hline
\end{tabular}

Table 3 of multiple regressions reveals the entered variables and the ones removed. The variables were entered simultaneously whereas, none was removed. The 'enter method' was used which represents the type of multiple regression that is standard.

Table 4. Model Summary

\begin{tabular}{|c|c|c|c|c|c|c|c|c|c|}
\hline \multirow[t]{2}{*}{ Model } & \multirow[t]{2}{*}{$\mathbf{R}$} & \multirow{2}{*}{$\begin{array}{l}\mathbf{R} \\
\text { Square }\end{array}$} & \multirow{2}{*}{\multicolumn{2}{|c|}{$\begin{array}{l}\text { Adjusted Std. } \\
\text { R Square Error of } \\
\text { the } \\
\text { Estimate }\end{array}$}} & \multicolumn{5}{|c|}{ Change Statistics } \\
\hline & & & & & $\begin{array}{l}\text { R } \\
\text { Square } \\
\text { Change }\end{array}$ & $\begin{array}{l}\text { F } \\
\text { Change }\end{array}$ & df1 & df2 & $\begin{array}{l}\text { Sig. F } \\
\text { Change }\end{array}$ \\
\hline 1 & & 366 & 357 & .528 & .366 & 42.435 & 2 & 147 & .000 \\
\hline
\end{tabular}

a. Predictors: (Constant), Social Media Content Marketing, Brand Awareness
The model summary Table 4 signifies R, R-square and adjusted $\mathrm{R}$-square. It indicates the correlation and variance between the variables. According to the results, the .366 variance in the consumer purchase decision is due to the differences of the predictors i.e. brand awareness and social media content marketing. The relationship between consumer purchase decision and the two predictors is $\mathrm{R}=0.605$ i.e. moderate.

\begin{tabular}{|c|c|c|c|c|c|c|}
\hline \multirow{3}{*}{\multicolumn{2}{|c|}{ Model }} & \multicolumn{4}{|c|}{ Table 5. Coefficients ${ }^{a}$} & \multirow{3}{*}{ Sig. } \\
\hline & & \multicolumn{2}{|c|}{$\begin{array}{l}\text { Unstandardized } \\
\text { Coefficients }\end{array}$} & \multirow[t]{2}{*}{ Standardizedt } & & \\
\hline & & B & Std. Erro & & & \\
\hline \multirow[t]{3}{*}{1} & (Constant) & 1.378 & .262 & & 5.253 & .000 \\
\hline & Brand Awareness & .176 & .059 & .213 & 2.974 & .003 \\
\hline & $\begin{array}{l}\text { Social Media } \\
\text { Content } \\
\text { Marketing }\end{array}$ & .432 & .063 & .488 & 6.830 & .000 \\
\hline
\end{tabular}

a. Dependent Variable: Purchase Decision

Table 5 represents a standardized Beta of brand awareness as 0.213 signifying a moderate input in explaining the variance in a consumer purchase decision. The $t$ value is 2.974 and significance $(p)$ value is 0.003 which is less than 0.05 , therefore, it leads to the conclusion that the first hypothesis "Brand awareness has a significant relationship with consumer purchase decision" is accepted.

The standardized Beta for social media content marketing is 0.488 . The $t$-value is 6.830 and significant $(p)$ value as 0.000 i.e. less than 0.05 so it leads to the conclusion that the second hypothesis "Social Media Content Marketing has a significant relationship with consumer purchase decision" is accepted.

\section{CONCLUSION}

As per the results generated in the previous chapter, it has been concluded that brand awareness has a weak positive significant relationship with the consumer purchase decision. Whereas, social media content marketing has a moderate positive significant relationship with the consumer purchase decision. The findings reveal that social media content marketing has high input in explaining the variance in consumer purchase decision i.e. 0.488.

The first objective of this study was to determine the relationship between brand awareness and consumer purchase decision, where the findings of the study result in a weak positive significant relationship between brand awareness and consumer purchase decision. This indicates that if consumers are well aware of the brand then there are higher chances of making a purchase decision since awareness helps them in clearing their doubts regarding the brand.

The second objective of the study was to examine the relationship between social media content marketing and consumer purchase decision. The results reveal that social media content marketing has a moderate positive significant relationship with consumer purchase decision which interprets that social media content marketing plays a major role in this technologically driven era, the strong content will persuade consumers towards the desired results i.e. making a purchase decision.

It is expected that this research would be of great help to the brands and consumers both. This will assist brands in understanding the need of creating brand awareness through social networking sites, where they can create virtual communities and get directly in contact with their current and potential consumer hence creating awareness for the brand. Consumers, however, can benefit from this study by understanding the fact that brand awareness is crucial for making a purchase decision. The social media content marketing will help consumers in getting brand insights through different means i.e. vlogging, reviews, videos, posts etc. Through consumer reviews and interaction, the brands will have access to consumer needs and desires.

There are many variables that impact the consumer purchase decision however, this study focused on two variables i.e. brand awareness and social media content marketing. Other variables that 
can be but are not part of this study are brand health, brand loyalty, brand image, and consumer engagement etc. These variables can also affect the consumer's purchase decision. Additionally, studies in future can be conducted on examining the impact of consumer reviews on potential customers at social media sites like Facebook, Instagram and Snapchat etc.

\section{References:}

Ashley, C., \&Tuten, T., (2015). Creative Strategies in Social Media Marketing: An Exploratory Study of Branded Social Content and Consumer Engagement. Psychology and Marketing. 32(1), 15-27.

Baines, P. \& Fill, C. (2014). Marketing, 3rd edn. Oxford: Oxford University Press.

Barreda A.A., Anil Bilgihan A., Nusair K., \&Okumus F. (2015). Generating brand awareness in Online Social Networks. Computers in Human Behavior 50 (2015) 600-609.

Cheung, C. M., Lee, M. K. \& Neil, R., 2008. The Impact Of Online Electronic Word-Of-Mouth: The Adoption Of Onlone Opinions In Customer Communities. Internet Research, 18(3), pp. 229-247.

Content Marketing Institute (2015). What Is Content Marketing?. Retrieved on 25 June 2015 from http://contentmarketinginstitute.com/whatiscontent-marketing/

Daeun Kim (2017). Vlog as a Branding Tool- How to Build a Brand with a Video Blog in Social Media.

Davidsson, P. \&Findahl, O. (2016). Swedes and The Internet. Internetfoundation in Sweden https://www.iis.se/docs/Svenskarna och internet 2016.pdf.

Dehghani\&Tumer (2015). A research on effectiveness of Facebook advertising on enhancing purchase intention of consumers. Computers in Human Behavior 49 (2015) 597-600.

Evans, D. 2008. Social Media Marketing. An Hour A Day. Indianapolis: Wiley Publishing

Gogoi, B. (2013). Study of antecedents of purchase intention and its effect on brand loyalty of private label brand of appare. International Journal of Sales \& Marketing, Vol. 3, No. 2, pp.73-86

Halpin, P., 2013. 'Like' Us: Social media and its influence on consumer decision making, with preference to high involvement products in Ireland, s.l.: s.n.

Hines (2017). 4 Ways to Measure Brand Awareness. Available at: https://www.fronetics.com/4-ways-measure-brand-awareness/

Holliman, G. \& Rowley, J., 2014. Busiiness to Business Digital Content Marketing: Marketer's Perception of Best Practise. Journal of Research in Interactive Marketing, 8(4), pp. 269-293.

Hsu, C. L., Lin, J. C. \& Chiang, H. S., 2013. The Effects of Blogger Recommendations on Customers' Online shopping intentions. Internet Research, 23(1), pp. 69-88.

Huotari, L., Ulkuniemi, P., Saraniemi, S. \&Malaska, M., 2015. Analysis of content creation in social media by B2B companies. Journal of business\& Industrial Marketing ,30(6), pp. 761-770.

Hur, W.-M., Ahn, K.-H. \& Kim, M., 2011. Building Brand Loyalty Through Managing Brand Community Committment. Management Desicion, 49(7), pp. 1194-1213

Hutter K., Hautz J., Dennhardt S. \& Fuller J. (2018). The impact of user interactions in social media on brand awareness and purchase intention: the case of MINI on Facebook. Journal of Product \& Brand Management, Vol. 22 Issue: 5/6, pp.342-351

Irfan, A., Rasli, A., Sulaiman, Z., Sami, A., \& Qureshi, M. I. (2019). The Influence of Social Media on Public Value: A systematic Review of Past Decade. Journal of Public Value and Administration Insights, 2(1), 1-6.

Irfan, A., Rasli, A., Sami, A., \& Liaquat, H. (2017). Role of Social Media in Promoting Education Tourism. Advanced Science Letters, 23(9), 87288731.

Karamian, Nadoushan M.A \&Nadoushan A.A (2015). Do Social Media Marketing Activities Increase Brand Equity? International Journal of Economy, Management and Social Sciences. Vol. (4), No (3), pp. 362365 .

Kima S., Choeb J.Y. \&Petrick J.F. (2018) The effect of celebrity on brand awareness, perceived quality, brand image, brand loyalty, and destination attachment to a literary festival. Journal of Destination Marketing \& Management 9 (2018) 320-329

Lamb, C.W., Hair, J.F., \& McDaniel, C. (2010). Marketing 4. Cengage Learning, p.91

Ludwig, S. et al., 2013. More than just words: The Influence of Affective Content and Linguistic Style Matches on Online Reviews on Conversion Rates. Journal of Marketing, Volume 77, pp. 87-103.

Mike Templeman. (2015). Content Marketing Doesn't Work. Forbes, August,
2015, Retrieved $\quad$ November 2015 from http://www.forbes.com/sites/miketempleman/2015/08/17/content marketing-doesnt-work/4/

Mintel, 2015. Social Networking - Ireland. [Online] Available at: http://academic.mintel.com/display/739944/ [Accessed august 2015].

Mintel, 2015. Social Shopping: Facebook Unveils Buy Button. [Online] Available at: http://academic.mintel.com/display/743612/?highlight.

Munir J., Shafi K., Khan F.A. \& Ahmed U.S. (2018). Elucidating the relationship of social media usage and e-WOM with brand related purchase decision involvement: an integrated meta-framework approach. WALIA journal 34(1): 59-64, 2018

Odden, L. (2013). Engaging more influencers and buyers with content marketing. Public Relations Tactics, 20(8), 18.

Patino, A., Pitta, D. A. \&quinones, R., 2012. "Social Media's emerging importance in market research". Journal of consumer marketing, 29(3), pp. 233-237.

Phillips, L., 2013. An investigation into the use of social media sites by young Irish consumers during the buying proccess, s.l.: s.n.

Pulizzi, J. (2013). B2C content marketing research: Strategy influences success. Content Marketing Institute, from http://contentmarketinginstitute.com/2013/10/2014-b2c- consumercontent-marketing/

Puro, P. (2013). Content marketing and the significance of corporate branding, Lappeenranta University of Technology.

Steimle., J., (April 19, 2014). What Is Content Marketing?. Retrieved on 25 June 2015 from http://www.forbes.com/sites/joshsteimle/2014/09/19/what-is-contentmarketing/

Touchette., B, Schanski., M., and Lee., S., L., (2015). Apparel Brands 'Use Of Facebook: An Exploratory Content Analysis Of Branded Entertainment Journal of Fashion Marketing and Management. 19 (2), pp. 107-119.

Vanauken, K., 2014. Using Social Media to Improve Customer Engagement and Promote Products and Services, s.1.: Henry Stewart Publications.

York, A. (2015, July 30). 5 Ways to Build Brand Loyalty through Social Media. Retrieved from www.sproutsocial.com: http://sproutsocial.com/insights/brand-loyalty/

Whiting, A. \& Williams, D., 2013. Why people use social media: a uses and gratifications approach. Qualitative Marketing Research, 16(4), pp. 362-369. 